\title{
SISTEM INFORMASI GEOGRAFIS KAWASAN BENCANA ALAM KABUPATEN POLEWALI MANDAR DENGAN GOOGLE MAPS
}

\author{
Hamka $^{1}$, Akhmad Qashlim² ${ }^{2}$ Syarli $^{3}$ \\ 1,2Program Studi Sistem Informasi, \\ 3Program Studi Teknik Informatika \\ Universitas Al Asyariah Mandar, \\ Jalan Budi Utomo No. 2 Madatte, Kab. Polewali Mandar, Prov. Sulawesi Barat
}

\begin{abstract}
ABSTRAK
Sistem informasi geografis berbasis web memungkinkan untuk dapat digunakan dalam mengumpulkan dan menganalisis data kritis pada wilayah tertentu. Google Maps sebagai teknologi berbasis web menyediakan layanan peta secara online. Google Maps telah digunakan pada berbagai bidang, seperti pementaan wilayah taman nasional, analisis dan perencanaan wilayah kota dan tata ruang, analisis curah hujan, dan eksplorasi kebijakan penggunaan lahan. Penelitian ini bertujuan untuk membangun sistem informasi geografis kawasan bencana Alam di Kabupaten Polewali Mandar menggunakan google maps, API Key di embedded kedalam pemprograman untuk memaksimalkan kinerja dari google maps. Data dalam penelitian adalah data atribut dan data spatial, data ini dipersiapkan dengan tiga tahap, pertama membuat data atribut yakni melakukan inventarisasi data informasi dan lokasi kawasan bencana, kedua, membuat data spatial yakni menemukan lokasi dalam peta dan mendapatkan koordinat kawasan, ketiga menghubungkan data atribut dan data spatial dengan query processing. Hasil penelitian ini, sebuah web sistem informasi geografis kawasan bencana alam polewali mandar yang disajikan menggunaan google Maps.
\end{abstract}

Kata Kunci: Bencana Alam, Maps, Polewali Mandar, GIS

\begin{abstract}
Web-based geographic information systems allow to be used in collecting and analyzing critical data in specific areas. Google Maps as a web-based technology provides online map services. Google Maps has been used in a variety of areas, such as the park's national park area, municipal landscape analysis and planning, rainfall analysis, and land use policy exploration. This research aims to build geographic information system of natural disaster area in Polewali Mandar Regency using google maps, API Key in embedded into programming to maximize performance from google maps. The data in the research is attribute data and spatial data, this data is prepared with three stages, first create data attribute that is doing inventory of information data and location of disaster area, secondly, make spatial data that find location in map and get coordinate area, third link attribute data and spatial data with query processing. The results of this research, a web geographic information system of natural disaster areas polewali mandar presented using google Maps.
\end{abstract}

Keywords: Natural Disaster, Maps, Polewali Mandar, GIS 


\section{PENDAHULUAN}

Sistem informasi geografis menyediakan geodatabase untuk menyimpan dan mengolah data spasial secara efektif dan efesien mampu memberikan analisis spasial dan visualisasi yang interaktif mengenai fenomena yang disimulasikan dan disajikan melalui sebuah pemodelan [4]. Sistem informasi geografis telah banyak digunakan di berbagai bidang, baik untuk kebutuhan bisnis, pementaan wilayah taman nasional [2], analisis dan perencanaan wilayah kota dan tata ruang [5], analisis curah hujan, termasuk untuk mendeteksi kondisi geografis serta digunakan sebagai alat untuk eksplorasi kebijakan penggunaan lahan yang mempertimbangkan depopulasi masa depan dan kerentanan perkotaan terhadap bencana alam [7]. Selain itu juga dapat berguna untuk melakukan penilaian terhadap kerusakan pasca kejadian bencana alam, mendeteksi bahaya dan resiko yang memunkinkan untuk terjadi serta memungkinkan untuk mengurutkan dan mengklasifikasikan serangkaian jenis data yang dihasilkan sehingga sangat bermanfaat bagi pengambil kebijakan untuk melakukan pencegahan dari awal [8].

Sistem informasi geografis dapat dibangun menggunakan bantuan software ArcView dengan berbagai metode seperti overlay dan intersection [10]. Untuk memaksimalkan kinerja dari sistem informasi geografismaka dapat dibangun menggunakan aplikasi berbasis web. Teknologi berbasis web dapat digunakan untuk mengumpulkan dan menganalisis data kritis pada wilayah tertentu [8]. Google Maps sebagai teknologi berbasis web yang diluncurkan tahun 2005 telah memberikan layanan aplikasi peta onlineberbasis Asynchronous JavaScript and XML (AJAX), ini merupakan cara baru untuk berinteraksi dengan google maps [6] teknologi ini mampuan mengirim data secara akurat baik real time maupun time seriesoleh karenanya dapat dimanfaatkan sebagai alat untuk membangun system informasi geografis [9].

Penelitian ini akan mencoba membangun sistem informasi geografis menggunakan google mapsdengan memanfaatkan googlemaps API (Application Programming Interface). Sistem akan melakukan inventarisasi data bencana kemudian disajikan melalui googlemaps dengan marker atau tanda untuk membantu pengguna melihat lokasi atau daerah rawan bencana.

\section{TINJAUAN PUSTAKA}

\subsection{Sistem Informasi Geografis - Geospatial}

Aplikasi geospasial menjadi bagian yang sangat diperlukan dari sistem informasi, Hal ini memberikan informasi terperinci mengenai data atribut objek spasial di dunia nyata. Karena pesatnya perkembangan teknologi dalam sistem informasi geografis berbasis web, penggunaan aplikasi geospasial berbasis web bervariasi dari kemampuan Geotagging hingga Geolocation. Oleh karena itu, pemanfaatan sistem informasi berbasis web yang efektif hanya dapat direalisasikan dengan mewakili dunia dalam tampilan aslinya, dimana atribut data objek spasial terintegrasi dengan objek spasial dan tersedia untuk pengguna di web, menggunakan API Google API. Dengan menggunakan Google Map API. Data atribut dari area studi yang tersimpan dalam database dapat diintegrasikan dengan data spasial yang ada di lapangan. Dengan demikian sistem ini akan meningkatkan keefektifan Sistem Informasi Geografis berbasis web (GIS) dan keseluruhan pengalaman pengguna [1].

\subsection{Kawasan Bencana Polewali Mandar}

Kabupaten Polewali Mandar adalah salah satu kabupaten yang berada diwilayah Sulawesi Barat. Secara geografis terletak antara $2^{\circ} 40^{\prime} 00^{\prime \prime} 3^{\circ} 32^{\prime} 00^{\prime \prime}$ Lintang Selatan dan $118^{\circ} 40^{\prime} 27^{\prime}$ ' $119^{\circ}$ 32' 27' Bujur Timur. Sebelah utara berbatasan dengan Kabupaten Mamasa, sebelah timur berbatasan dengan Kabupaten Pinrang, sulawesi selatan. Luas wilayah $2.022 .30 \mathrm{Km}$ dengan jumlah penduduk 367.761 jiwa. Kabupaten Polewali Mandar yang memiliki wilayah maritim dan agraris ternyata memiliki beberapa daerah yang rawan bencana seperti banjir dan lonsor. Data hasil pemetaan oleh Badan Penanggulangan Bencana Daerah (BPBD) menunjukkan beberapa kecamatan yang rawan bencana seperti Kecamatan Tinambung, Kecamatan Mapilli, Kecamatan Luyo, Kecamatan Matakali dan Kecamatan Binuang. Beberapa Kecamatan ini memiliki daerah yang sebagian besar adalah daerah pegunungan dan memiliki aliran sungan yang besar sehingga potensi bencana banjir dan lonsor sangat rentang di daerah tersebut. Untuk memantau daerah rawan bencana tersebut BPBD secara rutin melakukan pengecekan dilapangan terlebih ketika musim penghujan tiba. Dalam catatan BPBD bencana besar yang terakhir terjadi pada tahun 2009. Dugaan kuat terhadap bencana tersebut akibat rusaknya hutan pada daerah hulu yang mana daerah ini merupakan daerah yang susah untuk dijangkau dan dikontrol.

\subsection{Maps API}

Google Maps adalah layanan pemetaan web gratis oleh google yang menyediakan berbagai jenis informasi geografis. Google maps memungkinkan seseorang untuk 
mencari tempat atau dapatkan petunjuk arah dari satu tempat ke tempat lain selain itu juga dapat Melihat dan menavigasi gambar-gambar tingkat panorama horizontal dan vertikal dari berbagai kota di seluruh dunia. Pengguna juga dapat memanfaatkan google maps untuk memperoleh informasi spesifik seperti lalu lintas pada titik tertentu. Google Maps menyediakan API yang dapat digunakan untuk menyesuaikan peta dan informasi yang akan ditampilkan [11].

Google Maps menyediakan empat jenis peta. Antara lain:

- ROADMAP - Ini adalah tipe default. Jika Anda belum memilih jenisnya, ini akan ditampilkan. Ini menunjukkan tampilan jalan dari wilayah yang dipilih.

- SATELIT - Ini adalah jenis peta yang menunjukkan citra satelit dari wilayah yang dipilih.

- HYBRID - Jenis peta ini menunjukkan jalan utama pada citra satelit.

- TERRAIN - Ini adalah tipe peta yang menunjukkan medan dan vegetasi.

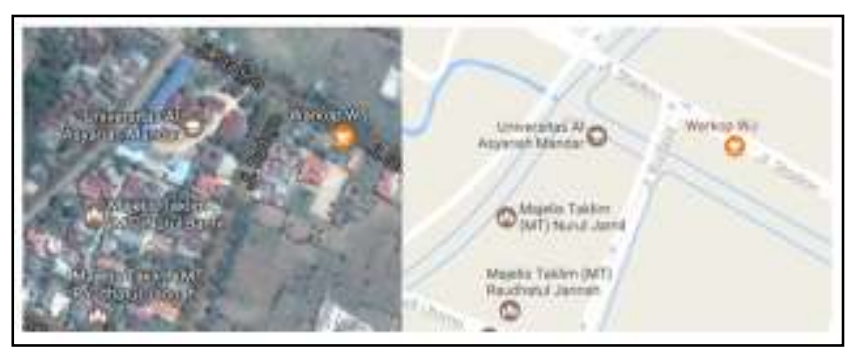

Gambar 2.1 Jenis Peta pada Google Maps

Peta dapat dimodifikasi menggunakan Google Map API yang terdiri dari blok kode, API singkatan dari Application Program Interface adalah satu set dari Rutinitas, protokol, yang menentukan bagaimana beberapa perangkat lunak Komponen harus berinteraksi satu sama lain. Google menyediakan Gambar satelit, peta jalan, peta terestrial, dan geocoding. Karena ini berbasis web maka sistem informasi geografis dengan Google Map adalah sumber dan pilihan yang baik bagi pengguna [1].

\section{METODE PENELITIAN}

\subsection{Persiapan Data}

Dalam penelitian ini kami mempersiapkan dua jenis data yang saling melengkapi dalam membangun web GIS aplication. Data ini dapat diperoleh dari berbagai sumber, termasuk dengan melihat kondisi alam, melakukan interview langsung dilapangan serta mengumpulkan data sekunder dari instansi Badan Penanggulangan Bencana Daerah (BPBD). Kedua jenis data ini akan menjadi dataset yang akan digunakan sebagai pedoman untuk menemukan dan mengetahui lokasi dilapangan, serta informasi mengenai lokasi tersebut. Ada Tiga tahap persiapan data, pertama data bencana di inventarisasi termasuk lokasi yang sesungguhnya, kedua, titik bencana atau menemukan lokasi bencana pada peta, ini dilakukan untuk mendapatkan koordinat lokasi baik dalam Lintang Selatan maupun Bujur Timur (LS-BT), setiap lokasi ini akan dibuatkan data marker (points). Pada web GIS Application yang kami buat proses ini akan dimudahkan dengan cara melihat peta kemudian melakukan klik pada lokasi bencana dalam peta setelah itu koordinat lokasi akan secara otomatis terekam dalam form yang telah disediakan dan tersimpan dalam database. Ketiga, menghubungkan antara data spasial (koordinat peta) dengan data atribut sebagai informasi yang memberikan keterangan mengenai peta atau lokasi pada peta. Dataset ini akan dibangun menggunakan MySQL. Lebih detail mengenai data dalam penelitian ini kami sajikan pada sub bab berikutnya.

\subsubsection{Data Atribut}

Data atribut yang dimaksud dalam penelitian yakni data bencana alam dan non bencana alam. Data bencana alam adalah bencana yang diakibatkan oleh evolusi alam seperti banjir, lonsor, dan angin puting beliun, sementara Data bencana non alam adalah bencana yang diakibatkan oleh ulah manusia seperti kebakaran pemukiman dan kecelakaan kerja. Data sample dapat dilihat pada tabel 3.1. Data atribut kawasan bencana.

Tabel 3.1. Data Atribut Kawasan Bencana

\begin{tabular}{|l|l|l|l|}
\hline NO & \multicolumn{1}{|c|}{ Lokasi } & Jenis Bencana & $\begin{array}{l}\text { Kategori } \\
\text { Bencana }\end{array}$ \\
\hline 1 & Tubbi & $\begin{array}{l}\text { Angin Puting } \\
\text { Beliun }\end{array}$ & $\begin{array}{l}\text { Bencana } \\
\text { Alam }\end{array}$ \\
\hline 2 & Allu & Banjir bandang & $\begin{array}{l}\text { Bencana } \\
\text { Alam }\end{array}$ \\
\hline 3 & Matakali & $\begin{array}{l}\text { Kebakaran } \\
\text { Pemukiman }\end{array}$ & $\begin{array}{l}\text { Bencana } \\
\text { Non Alam }\end{array}$ \\
\hline 4 & Wonomulyo & $\begin{array}{l}\text { Kebakaran } \\
\text { Pemukiman }\end{array}$ & $\begin{array}{l}\text { Bencana } \\
\text { Non Alam }\end{array}$ \\
\hline 5 & Binuang & $\begin{array}{l}\text { Angin Puting } \\
\text { Beliung }\end{array}$ & $\begin{array}{l}\text { Bencana } \\
\text { Alam }\end{array}$ \\
\hline
\end{tabular}

Sumber: Informaman Warga 
Tabel 3.1. merupakan data yang kami himpun dari berbagai sumber data tersebut juga kami persiapkan untuk membuat grafik. Data tersebut akan coba kami sajikan dengan memanfaatkan query fushion.chart yang di sematkan kedalam sistem. Hasil grafik dapat dilihat pada gambar

\subsubsection{Data Spasial}

Data spasial yang dimaksud dalam penelitian adalah data koordinat peta atau lokasi bencana yang ditunjukkan di peta. Data koordinat ini kami dapatkan langsung dari google maps. Tabel 3.2. menunjukkan data spatial kawasan bencana di Polewali Mandar.

Tabel 3.2. Data Spatial Kawaan Bencana

\begin{tabular}{|l|l|c|c|}
\hline NO & Lokasi Bencana & Bujur Timur & $\begin{array}{c}\text { Lintang } \\
\text { Selatan }\end{array}$ \\
\hline 1 & Tubbi & $118.85^{\prime} 86^{\prime}{ }^{\prime}$ & -3.2340115 \\
\hline 2 & Allu & $118.56^{\prime} 84^{\prime}$ & -3.2174333 \\
\hline 3 & Matakali & $119.22^{\prime} 62^{\prime}$ & -3.3622096 \\
\hline 4 & Wonomulyo & $119.17^{\prime} 011^{\prime}$ & -3.4240591 \\
\hline 5 & Binuang & $119.35^{\prime} 74^{\prime \prime}$ & -3.4282517 \\
\hline
\end{tabular}

Data spatial berupa koordinat peta telah kami cocokkan dengan data lokasi sebenarnya dan. Data ini akan dihubungkan dengan data atribut. Kemudian disajikan secara visual diatas peta google maps. Selanjutnya web GIS Application dibuat dengan bahasa pemrograman, kerangka sistem web GIS Application dapat dapat dilihat pada gambar 4.1.

Sistem yang akan dibangun memiliki administrator web sistem, bagian ini akan menginput data informasi bencana kedalam database server, sementara itu google maps API Key di embedded kedalam administrator web sistem dan data spatial dari google maps dimasukkan kedalam data base hasil query processing akan menampilkan peta beserta data informasi bencana.

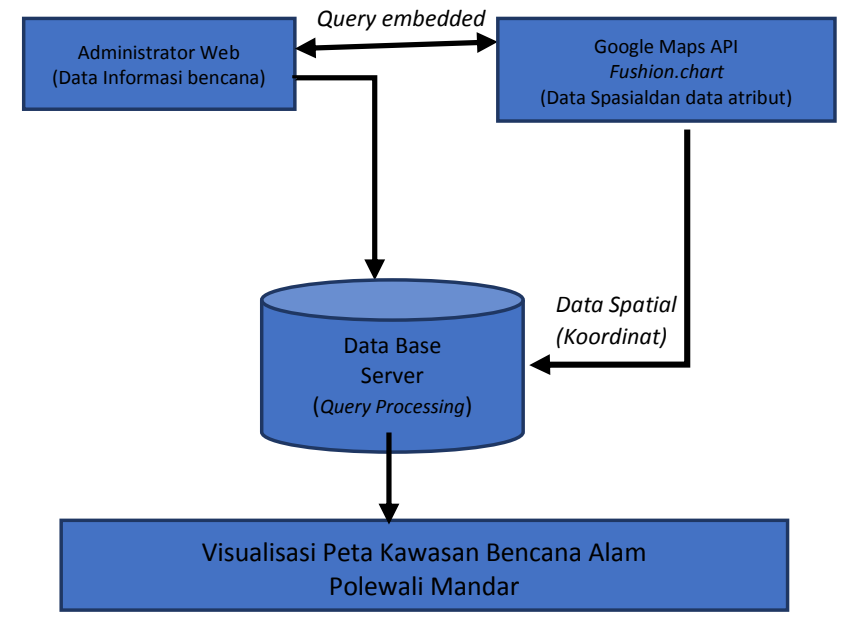

Gambar 4.1. Kerangka Sistem Web GIS Application

\subsection{Embedded API Google Maps}

Setelah interface program selesai dibuat maka selanjutnya akan dikoneksikan google maps, agar ini bekerja dengan baik maka dilakukan proses embedded google API key kedalam pemrograman. Script file dapat dilihat dikotak berikut.

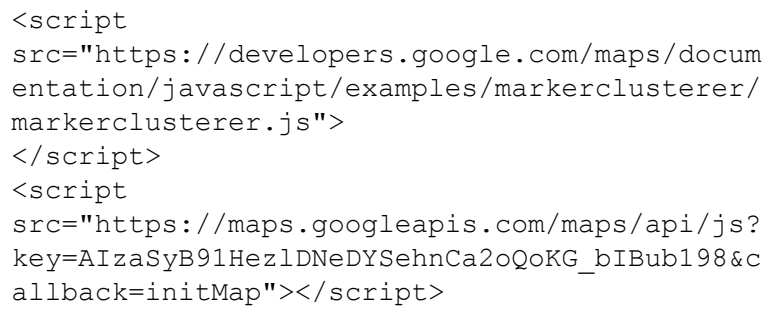

Ketika pengguna terhubungan dengan halaman peta maka permintaan akan dikirm ke google maps dan google akan menampilkan peta sesuai data spatial yang terdapat dalam database MySQL sementara informasi atributnya disajikan ketika pengguna melakukan klik pada marker yang telah dibuat.

\section{HASIL PENELITIAN}

Sebuah sistem informasi geografis (web GIS application) menggunakan google maps API untuk melakukan visualisasi data mengenai kawasan bencana alam diwilayah Polewali Mandar, Sistem informasi geografis berbasis web dibangun menggunakan perangkat lunak adobe dreamweaver untuk membuat halaman HTML, PHP, CSS dan Javascript sementara API Key di embedded kedalam sistem. Infrastruktur sistem web GIS application dapat dilihat pada gambar 4.1. 


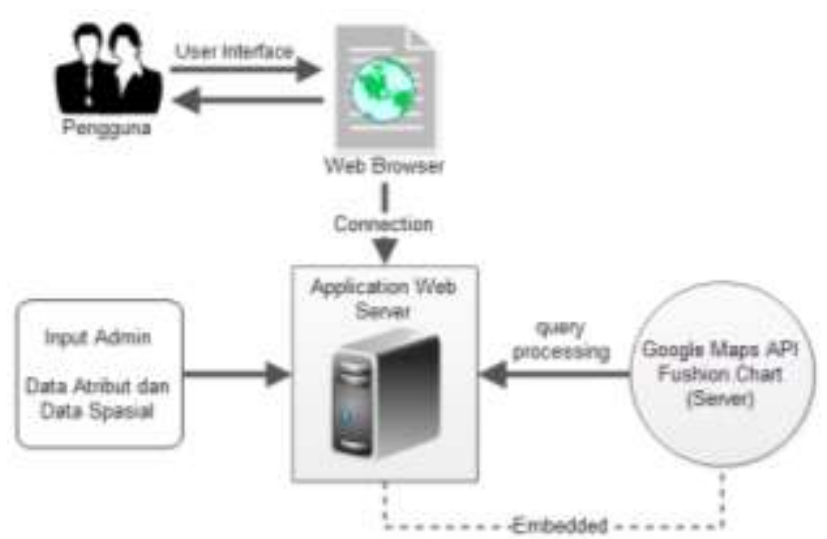

Gambar 4.1. Infrastruktur sistem web GIS application

Pada dasarnya ada dua jenis arsitektur yang dibangun pada web GIS application yakni sisi pengguna (end user) dan sisi administrator. Infrastruktur sistem yang ditunjukkan pada gambar 4.1. memberikan informasi mengenai pengguna yang terlibat dalam sistem. Aplikasi web server merupakan web GIS Application yang berisi informasi mengenai data atribut dan data spasial. Pengguna akhir yang berinteraksi dengan sistem melalui user interface sebuah web brower akan terhubung ke perangkat server. Pada aplication web server telah di embedded query untuk menampilkan Google Map server dan fushion.chart. Administrator menginputkan data mengenai informasi bencana dan lokasi bencana di peta, informasi ini akan disajikan bersamaan dengan peta. Administrator dapat menambahkan lokasi dan informasi lainnya. Halaman user interface dapat dilihat pada 4.2 .

\subsection{Web GIS Application}

Web GIS Application berhasil dibuat dan terhubung dengan lapisan google maps API, sebuah interface untuk memungkinkan interaksi pengguna selain administrator yakni Halaman pengunjung yang ditunjukkan pada gambar 4.2. Halaman pengunjung akan dikelolah oleh administrator ini ditunjukkan pada gambar 4.3. Selain itu juga ditambahkan grafik pie dan grafik batang yang diemmbedded dari query fushion.chart ditunjukkan pada 4.4 .

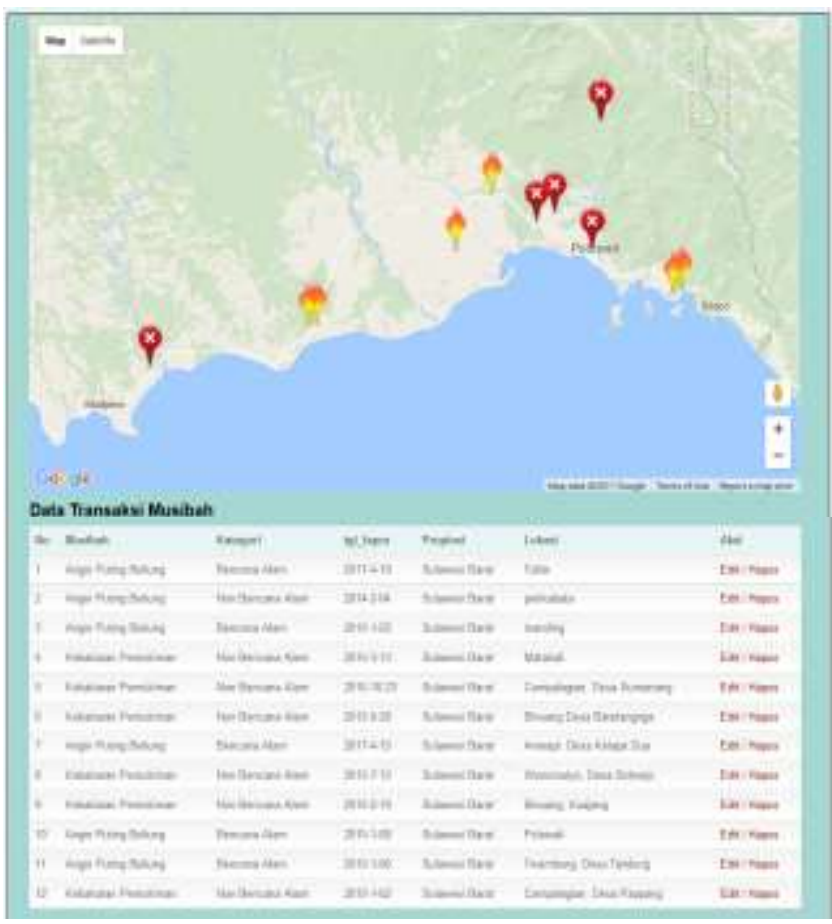

Gambar 4.2.Halaman pengunjung web GIS Application

Halaman pengunjung menampilkan marker pada setiap posisi yang ditunjukkan oleh data geospasial. Data geospasial berupa koordinat peta yang telah disimpan dalam data base. Berikut ini adalah kode untuk menampilkan marker pada peta.

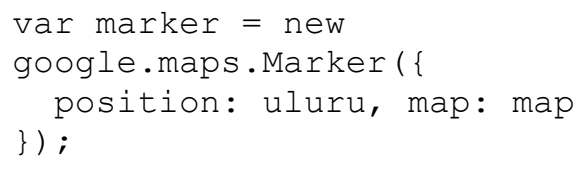

Halaman administrator disediakan untuk melakukan konrol atau pengaturan pada peta, baik data atribut maupun data spatial. Halaman administrator web GIS application ditunjukkan pada gambar 4.3.

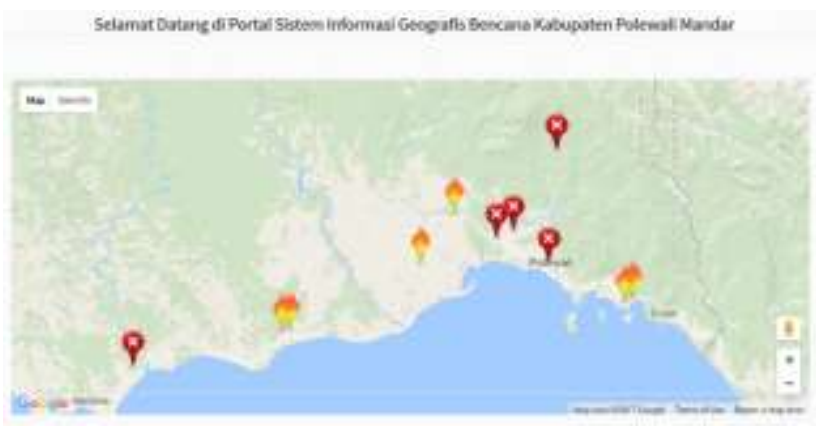

Gambar 4.3. Sistem Informasi Geografis Kawasan Bencana Alam 
Data table yang dimasukkan kedalam sistem merupakan data atribut, ini dimaksudkan untuk memenuhi standar GIS [3]. Data pada tabel dapat ditambah dirubah dan dihapus. Setiap data ditambah atau diperbaharui maka pengguna akan langsung melihat perubahan kondisi pada peta. Peta google maps API yang kami gunakan memiliki dua jenis icon untuk membedakan jenis bencana, ikon merah untuk bencana alam dan icon api untuk bencana non alam. Informasi mengenai bencana alam dan bencana non alam juga kami sajikan dalam bentuk grafik menggunakan query fushion.chart. grafik dapat dilihat pada gambar 4.4 .

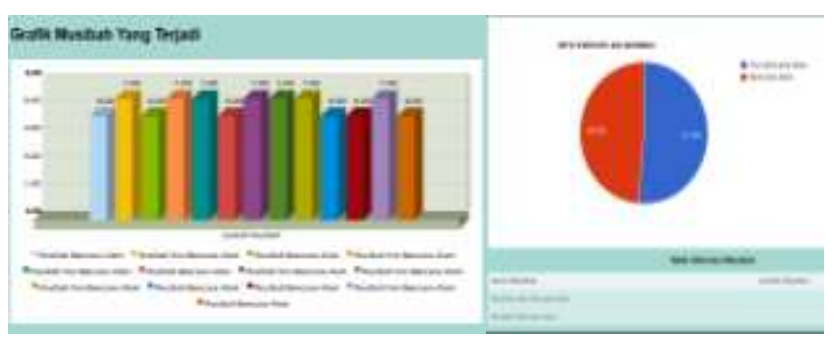

Gambar 4.4. Grafik kejadian bencana

Pie grafik menunjukkan persentase kejadian bencana alam dan bencana non-alam (aktivitas manusia), sementara grafik batang menunjukkan data yang lebih spesifik mengenai benca yang terjadi baik karena evolusi alam maupun non-alam.

\section{KESIMPULAN}

Kemampuan melakukan embedded query kedalam sistem adalah upaya untuk memberikan informasi kepada pengunjung dalam bentuk visual, baik mengenai lokasi, kawasan, atau daerah yang sebenarnya maupun mengenai informasi bencana yang terdapat didaerah tersebut. Sistem ini juga dilengkapi pencarian lokasi bencana tetapi belum termasuk pencarian lokasi berdasarkan multikriteria sehingga pengunjung belum dapat mencari lokasi hutan hujan tropis, lokasi sebaran flora dan fauna. Tidak ada perangkat lunak atau plug-in khusus yang diperlukan dari pengguna akhir untuk dapat mengakses informasi yang diinginkan pada google maps. Ini juga dapat diakses diberbagai platform dan browser yang berbeda. Meski demikian

google maps menyediakan komunikasi dua arah interaktif antara pengguna dan penyedia informasi, oleh karena itu kecepatan akses akan dipengaruhi oleh koneksi internet karena setiap kali permintaan dibuat, dokumen HTML baru harus meminta data ke server administrator dan server google maps. Sistem ini dapat dikembangkan dalam bentuk lain seperti smart phone untuk kepentingan mobile.

\section{DAFTAR PUSTAKA}

[1] Akanbi A. K, Agunbiade O. Y., 2013, Integration of a city GIS data with Google Map API and Google Earth API for a web based 3D Geospatial Application, International Journal of Science and Research, 2(11), pp. 200-203.

[2] Browna,G.B., Weberc, D., 2011, Public Participation GIS: A new method for national park planning, Landscape and Urban Planning 102 1-15, 2011 Elsevier.

[3] Bowie, Gregory D., Millwardb,Andrew A., Bhagataa, Nikesh N., 2014, Interactive mapping of urban tree benefits using Google Fusion Tablesand API technologies, Graduate Program in Spatial Analysis, Department of Geography, Ryerson University, Toronto, Canada.

[4] Choa, S., Bellemansa, T., Janssensa, D., Wetsa, G., 2014, Integrating GIS and FEATHERS: A Conceptual Design,The 5th International Conference on Ambient Systems, Networks and Technologies (ANT-2014), Procedia Computer Science 32405 - 412 Elsevier

[5] Grunwald, L., Heusinger, J., Weberv, S., 2017, A GIS-based mapping methodology of urban green roof ecosystem services applied to a Central European city, Climatology and Environmental Meteorology, Institute of Geoecology, 4-1

[6] Hu, Shunfu, Dai, Ting, 2013,Online Map Application Development Using Google Maps API,SQL Database, and ASP.NET, International Journal of Information and Communication Technology Research, 2223-4985

[7] Karashima, K., Akira, Ohgai., Saito, Y., 2014, A GIS-based Support Tool for Exploring Land Use Policy Considering Future Depopulation and Urban Vulnerability to Natural Disasters - A Case Study of Toyohashi City Japan, Procedia Environmental Sciences 22148 - 155, Elseiver

[8] Mejria, O., Menonia,S., Matiasb,K., Aminoltaheric, N., 2017, Crisis information to support spatial planning in post disaster recovery, International Journal of Disaster Risk Reduction 22 46-61

[9] Rasmayani, 2016, Pemanfaatan Teknologi Google Maps API Untuk Aplikasi Laporan Kriminal Berbasis Android Pada Polres 
Makassar, Jurnal Penelitian Pos dan Infirmatika $185-200$

[10] Suaib, Qashlim, Akhmad, 2014, Inventarisasi data Bencana Alam Pada Kecamatan Tappalang Kambupaten Mamuju, Seminar Nasional Industri dan Teknologi (SNIT), Politeknik Negeri Bengkalis, Riau.

[11] Tutorial Point Company Team, 2006, Google Maps, https://www.tutorialspoint.com/ 